Cornell Law Library

Scholarship@Cornell Law: A Digital Repository

Cornell Law Faculty Publications

$1-1-2009$

\title{
Plaintiphobia in State Courts? An Empirical Study of State Court Trials on Appeal
}

Theodore Eisenberg

Cornell Law School, ted-eisenberg@lawschool.cornell.edu

Michael Heise

Cornell Law School, michael-heise@lawschool.cornell.edu

Follow this and additional works at: http://scholarship.law.cornell.edu/lsrp_papers

Part of the Courts Commons

\section{Recommended Citation}

Eisenberg, Theodore and Heise, Michael, "Plaintiphobia in State Courts? An Empirical Study of State Court Trials on Appeal" (2009). Cornell Law Faculty Publications. Paper 79.

http://scholarship.law.cornell.edu/lsrp_papers/79 


\title{
Plaintiphobia in State Courts? An Empirical Study of State Court Trials on Appeal
}

\author{
Theodore Eisenberg and Michael Heise
}

\begin{abstract}
Prior federal civil appellate studies show that appeals courts overturn jury verdicts more than bench decisions and that defendants fare better than plaintiffs on appeal. Attitudinal and selection effect hypotheses may explain the appellate court tilt favoring defendants. This study presents the first statistical models of the appeals process for a comprehensive set of state court civil trials to test theories on appellate outcomes. Using data from 46 large counties on 8,038 trials and 549 concluded appeals, we find that appellate reversal rates for jury trials and defendant appeals exceed reversal rates for bench trials and plaintiff appeals. The reversal rate for plaintiff appeals is 21.5 percent, compared with 41.5 percent for defendant appeals. The reversal rate for jury trials is 33.7 percent, compared with 27.5 percent for bench trials. Descriptive analyses and more formal models suggest that appellate judges' attitudes toward trial-level adjudicators help explain these asymmetric outcomes.
\end{abstract}

\section{INTRODUCTION}

Appealed cases form the core of what most observers know about the legal system. Appellate opinions dominate casebooks, establish doctrine that binds trial courts, and are more readily available for research use than are the mass of unappealed cases. Yet perceptions of the legal system based on appellate or published opinions can be distorted. For example, Siegelman and Donohue (1990) showed that federal court employment

THeodore eisenberg is Henry Allen Mark Professor of Law and Adjunct Professor of Statistical Sciences, Cornell University; Michael heise is Professor of Law, Cornell Law School. We thank Dawn M. Chutkow, Kevin M. Clermont, an anonymous referee, and seminar participants at Boston University, Duke University, the University of Houston, and the University of Michigan for comments.

[Journal of Legal Studies, vol. 38 (January 2009)]

(C) 2009 by The University of Chicago. All rights reserved. 0047-2530/2009/3801-0005 $\$ 10.00$ 
discrimination case opinions constitute only the tip of a large underlying iceberg of adjudicated discrimination cases.

Although we know a reasonable amount about these distortions that are introduced by observing opinions in federal court, the rates of appeal, and the influences on the decision to appeal in federal court (Clermont and Eisenberg 2001; Eisenberg 2004), similar knowledge about these matters in state courts does not exist. Yet, as Galanter (2004) notes, the bulk of civil litigation-including appellate litigation-occurs in state courts. This article uses a unique data set (U.S. Department of Justice 2006) that followed a comprehensive cohort of tried state court cases through their conclusion at the appellate level. Using these data, we present the first broad systematic empirical study of state court appeal rates and outcomes not subject to traditional concerns about opinion availability and lack of information about all trial outcomes.

Data limitations have not dampened the formation of either opinions or conventional wisdom concerning the appeals system. Indeed, the absence of data enhances the influence of opinions, anecdotes, and casual impressions. For example, in the appeals context, advice to lawyers typically emphasizes the sanctity of jury verdicts and warns that "appellate challenges to jury findings rarely succeed" (Somerville 1992, p. 25). Not surprisingly, such advice informs concrete decisions at the beginning of the litigation process when a lawyer's decision about whether to select a jury trial pivots partly on popular perceptions about the comparative resilience of jury outcomes to appellate review (see Haydock and Sonsteng 1990, p. 81 ).

Holding conventional wisdoms and perceptions up to empirical light frequently uncovers surprises (see, for example, Clermont and Eisenberg 1992). One set of surprises about civil appeals emerged from studies of federal courts drawing on data from the Administrative Office of the U.S. Courts (AO) (Eisenberg 2004; Clermont and Eisenberg 2002b). Contrary to received wisdom, for example, these studies found that jury verdicts were more prone to reversal than were bench verdicts (Clermont and Eisenberg 2001). In addition, defendants' success with appeals systematically and substantially exceeded plaintiffs' success, and both success rates were on average far below 50 percent (Clermont and Eisenberg 2002b), despite informed speculation that appellate success rates should be near 50 percent (Priest and Klein 1984). Moreover, Clermont, Eisenberg, and Schwab (2003) found these general findings presented with even greater force within specific case types.

Systematic research on state civil appeals of trials can accomplish 
several goals. Such research helps test litigation theories generated by law and economics and other scholars. Testing theories using state appeals is warranted in its own right because appeals provide the bulk of our knowledge of the legal system and "the great preponderance of trials, both civil and criminal, take place in the state courts" (Galanter 2004, p. 506). Comparison with federal appellate research provides an opportunity to assess the consistency of state and federal court patterns as well as the robustness of findings from prior work on federal appeals. This study of state appeals benefits from data from the Bureau of Justice Statistics (BJS) and the National Center for State Courts (NCSC), which, unlike the AO data set used in federal appeals studies, are designed expressly for systematic study of the appeals process. ${ }^{1}$ By following a cohort of trials to conclusion, these state court data avoid the problems of ex post efforts to match trial outcomes and appeals (see, for example, Eisenberg 2004; Clermont and Eisenberg 2002b) and permit unprecedented analyses of state court appeals. Although helpful descriptive work using the state appeals data set sketches the broad contours of the state appeals terrain (U.S. Department of Justice 2005), our study is the first systematic empirical analysis of state appellate activity that models critical aspects of the state civil appeals process and empirically tests the competing hypotheses on appellate outcomes.

Key findings in this study are that, similar to civil trials in state courts, appeals are comparatively rare events. In our data set of 8,038 completed state court trials, only 12 percent stimulated an appeal. Of the 965 trials that continued to the appeal process, 549 , or just over one-half, culminated in a final appellate court decision. Finally, rarer still are cases that exhausted a state's full appellate process, from the trial court to the highest appellate tribunal. Of the 965 cases that initiated appeals, only 24 cases reached a state's appellate court of last resort. ${ }^{2}$ For all practical purposes, trial court decisions effectively terminate the bulk of the legal disputes they address.

We also find that the state appellate court results are asymmetric in two noteworthy ways. First, although state appellate courts affirmed trial court decisions in more than two-thirds of all cases, appellate courts were more likely to upset jury trials than bench trials. Second, defendants were far more successful than plaintiffs in securing a reversal of a trial

1. Appeals studies using Administrative Office data, while important, must work with data sets not expressly designed for appeals studies.

2. The 24 cases that reached a state's appellate court of last resort represent 2.5 percent of the cases appealed and .3 percent of cases litigated through trial. 
court outcome. A plaintiff victory in front of a jury was the most likely scenario to generate an appellate court reversal. Our results also suggest that appellate court attitudes and assumptions about trial courts likely shape the observed pattern of appeals' outcomes even after accounting for the selection of cases to appeal. This study's findings largely comport with previous findings from studies of federal appeals and support explanations that include the attitudinal hypothesis as well as selection effect considerations.

Section 2 briefly describes the two major theories that compete to explain the asymmetrical appellate outcomes. Section 3 describes the data, methodology, and research design. Section 4 presents descriptive results with a particular emphasis on the contours of the stream of cases from trial verdict through the appeals processes. Section 5 reports regression results that confirm and refine the core results in Section 4. Section 6 concludes.

\section{COMPETING THEORIES ON ASYMMETRICAL APPELLATE OUTCOMES}

As we illustrate below, state court appellate outcomes systematically favor defendants, especially defendants who lost jury trials. Our results generally comport with similar asymmetrical findings in federal appellate courts (Clermont and Eisenberg 2002b). Theory supplies two hypotheses that compete to explain our central finding of an appellate court tilt favoring defendants-the attitudinal and selection effect hypotheses.

\subsection{Differential Attitude Hypothesis}

The differential attitude hypothesis (hereinafter, the "attitudinal hypothesis") $)^{3}$ emphasizes the possibility that either trial courts exhibit a pro-plaintiff bias or appeals courts perceive (or misperceive) trial courts as being pro-plaintiff. Notable anecdotal evidence of different trial court and appellate perspectives, and of appellate suspicion about trial court behavior, comes from the U.S. Supreme Court's decision in Cooper Industries, Inc. v. Leatherman Tool Group, Inc. (532 U.S. 424 [2001]). That case requires appellate courts to "apply a de novo standard of review when passing on district courts' determinations of the constitu-

3. We use the term "attitudinal" with some caution in this context. Although the term has a specific meaning in the literature on judicial decision making (see, generally, Segal and Spaeth 2002), we use the term here to refer not to judicial background or belief variables but rather to group-level attitudinal differences between appellate and trial court judges. 
tionality of punitive damages awards" (532 U.S. 424, 436). Such nondeferential review of trial court decisions about an issue often involving the size of awards would be unnecessary absent a belief that appellate and trial courts have differing attitudes. Decisional bias is implied by differences in trial and appeals court outcomes as well as the starkly asymmetrical distribution of appeals outcomes between plaintiffs and defendants. This hypothesis assumes that bias can influence appellate (and trial) outcomes, and this assumption enjoys empirical support (LoPucki and Weyrauch 2000).

What might plausibly account for an appellate court bias against plaintiffs, and what are we to make of it? First, trial court bias favoring plaintiffs may exist. One source of potential bias flows from natural empathy with a victim, an impulse to make victims whole, and a willingness to redistribute wealth from a comparatively deeper economic pocket to an aggrieved plaintiff. Unlike appellate courts, trial courts do not deal with a "cold" record and are less concerned with opinion writing and the future effect of their decisions (Tigar 1993).

Second, even if trial court bias does not exist, appellate courts may assume that such a bias exists and act accordingly. Indeed, persistent public characterizations of a liability crisis may help frame appellate courts' perceptions of trial court decisions. Prior research emphasizes that persistent misperceptions of a liability crisis can pervade not only the populace but the legal profession as well (Galanter 2006; Clermont and Eisenberg 1992). Many envision an "out of control" civil justice system (Galanter 2006, p. 21). In such a context, why should we assume that appellate judges are immune (Robertson 1999)? Regardless of whether appellate courts accurately or inaccurately assume that trial courts favor plaintiffs, appellate courts may tilt in defendants' favor to offset a perceived trial court bias favoring plaintiffs. Thus, for either reason (or both), one might expect trial courts to favor plaintiffs relative to appellate courts.

\subsection{Selection Effect Hypothesis}

A second plausible hypothesis is case-selection based and posits that plaintiffs and defendants systematically appeal cases of different quality and that these different case streams explain asymmetric appellate reversal rates. Systematically different cases might flow from three possible sources: differential stakes, settlement incentives, and differences between defendants and plaintiffs. Generating specific quantitative predictions based on selection effect considerations can be difficult (Shavell 
1996), but ignoring such considerations would be naive (Clermont and Eisenberg 2002a).

Plaintiffs and defendants might possess different stakes in a lawsuit, and, if so, selection theory implies that the side with comparatively more at stake should be willing to settle its weakest cases and, in so doing, increase its win rate for those cases fully adjudicated (Clermont and Eisenberg 2001). The plaintiff win rate at trial was approximately 55.4 percent (U.S. Department of Justice 2004), and it remains possible that the slightly higher plaintiff trial win rate might evidence plaintiffs' higher stakes (Clermont and Eisenberg 2001). Just as plaintiffs' higher stakes in cases should boost their trial win rates, the selection hypothesis also predicts that the side with lower stakes (defendants), having lost more at trial, would appeal more. More important, however, is that plaintiffs, whose hypothesized higher case stakes should make them more selective about what cases to push at trial, should be equally careful about only pushing strong cases on appeal. If so, appeal reversal rates for plaintiffs would approximate, if not exceed, the defendants' reversal rates.

Differences in plaintiff and defendant settlement incentives would help explain differences in plaintiff and defendant reversal rates on appeal. Even assuming that plaintiff-appellees and defendant-appellants have different incentives when it comes to settlement strategy, to cohere, the settlement explanation must also assume that defendants who lost at trial would settle their weakest appeals and that defendants who were victorious at trial would stonewall appealing plaintiffs on appeal. Such strategic defendant conduct, however, strikes us as implausible so long as one assumes that some defendants who lost at trial with objectively weak cases are nonetheless still motivated to file an appeal in the hope of a long-shot victory and with the certainty of prolonging the appellate process if only to delay the legal day of reckoning (Dalton 1985; Hyman et al. 2007). After all, defendants who pressed objectively weak cases to trial may not suddenly change attitudes and tactics posttrial.

Selection effect theorists might posit further differences that distinguish plaintiffs and defendants that could account for asymmetrical appellate reversal rates. For example, where losing defendants might assess settlement decisions through a cost-benefit lens, Posner (1985) notes that losing plaintiffs, by contrast, might place more weight on the desire to "be heard fully" on appeal, perhaps regardless of their objective chances on appeal (Barclay 1999, pp. 12-14). If so, one would expect an appellate rate to favor defendants, as they would be pursuing objectively stronger appeals. 
Prior work on selection theory and federal appellate outcomes includes an innovative effort by Kessler, Meites, and Miller (1996, pp. 237, 242-48) linking asymmetric stakes, costs, and information and other factors (what they termed a "multimodal approach") to specific case categories to test the factors' association with outcomes at trial and on appeal. They hypothesized that different selection-related factors tugged in different directions, with one factor, agency costs, conceivably increasing, decreasing, or not affecting plaintiff win rates. They concluded that the multimodal approach helped explain appellate outcomes, although only high defendant stakes and high awards were statistically significantly associated with appellate victories. High defendant stakes were associated with defendant wins on appeal. High awards were associated with plaintiff wins on appeal.

Taken together, selection effect considerations and prior results suggest that generating specific predictions from selection effect theory is challenging. Nevertheless, the Kessler, Meites, and Miller (1996) focus on possible differences across case categories is plausible, and one can, at a minimum, regard selection effect considerations as forecasting heterogeneous appellate reversal rates across case categories because of, inter alia, varying plaintiff-defendant differences in stakes across case categories.

\section{DATA, METHODOLOGY, AND RESEARCH DESIGN}

Two distinct, although related, data sets supply the data necessary for this study. First, the Civil Justice Survey of State Courts, a project of the NCSC and the BJS, gathers data directly from state court clerks' offices on tort, contract, and property cases disposed of by trial during calendar year 2001. The 2001 data set covers state courts of general jurisdiction in a random sample of 46 of the nation's 75 most populous counties. The 75 counties from which the sample of 46 was drawn include approximately 37 percent of the 1990 U.S. population and about one-half of all civil lawsuits filed in state courts. The 2001 data set includes information on 8,038 trials (U.S. Department of Justice 2004, pp. 4-5).

The second data set used in this study enhanced the first. The NCSC and BJS implemented a follow-up study that supplemented the 2001 trial study by tracking the 1,204 cases in which the trial verdict or judgment that concluded by trial during the calendar year 2001 was 
appealed to an intermediate appellate court or a state's court of last resort by April 2005 (U.S. Department of Justice 2005). Of this universe of 1,204 appeals, 47 (3.9 percent) were excluded from many of our analyses because the appeals lacked critical information about which party prevailed at trial.

Because we are most interested in appeals from trial court decisions clearly adverse to a party, we excluded cases in which it was not clear that the nature of the appeal was adverse. For example, if the trial court ruled for the plaintiff, most would expect that the defendant would be the appellant in any appeal. Conversely, where the trial court ruled for the defendant, one would expect the plaintiff to be the appellant. For the most part (in 83.4 percent of the appeals), these expectations were met. Discarding the small subgroup of nonadverse appeals generates a universe of 965 usable appeals and permits a more precise picture of appeals by plaintiffs and defendants from the trial court judgments entered against them. The appeal rate, drawn from the pool of adverse appeals, is the percentage of trial court judgments for one party or the other that the losing party puts onto the appellate docket. ${ }^{4}$

After so filtering, computations of reversal and affirmance rates were straightforward. The reversal rate is the percentage of appeals that generate a formal legal conclusion that either reversed ${ }^{5}$ or remanded the trial court decision. The affirmance rate, by contrast, is the percentage of cases that generated an appellate court decision affirming the trial court.

Merging the two NCSC and BJS data sets generates a unique source of data: a longitudinal view of the universe of state appellate activity drawn from the most representative sample of state trial activity in the United States. These data facilitate the systematic study of appeals of trials. With direct access to the state court clerk's offices, as well as approximately 100 trained coders recording data, the data set avoids traditional limitations incident to relying on litigants or third parties to report. Self-reports, common in many commercial verdict reporters, typically overstate plaintiff win rates and damage award levels (Eisenberg et al. 1997; Merritt and Barry 1999; Moller, Pace, and Carroll 1999).

Despite the state civil appeals data set's unique strengths, it is not without limitations. First, our data are limited to tried cases and there-

4. For a similar approach to defining the appeal rate, see Clermont and Eisenberg (2001, p. 129).

5. By "reversed" we mean reversed in whole or in part. 
fore do not include cases appealed after dispositive pretrial motions. Second, because our sample focuses on the nation's largest counties and state courts of general jurisdiction, the data might not convey those aspects of the civil justice system, if any, that are peculiar to smaller counties or rural areas or to cases heard in special-jurisdiction courts (Sullivan, Warren, and Westbrook 1989; Eisenberg et al. 1997; Heise 2000). Third, the focus on state courts precludes generating implications for federal courts.

Selection effects also influence our data set in various ways. As Table 1 illustrates, the stream of cases encounters an array of filters as it proceeds from the civil dispute stage through the trial and appeals processes. As only a small fraction of civil actions filed reach trial, the pool of tried cases may systematically differ from the larger pool of civil disputes from which they emerged. The appeals process itself imposes additional filters. Only 12 percent of the tried civil cases initiated the appeals process (although the percentage is slightly higher if one includes the ambiguous, nonadverse appeals). ${ }^{6}$ Fewer cases still ( 6.8 percent) pursued the appeals process to decision. That is, of the cases that began the appeals process, just over one-half (56.9 percent) completed at least the first level of it, disposition by an intermediate appellate court.

There are strong theoretical reasons to expect these selection effects to result in a nonrandom sample of cases on appeal. Expectations theory predicts that objectively strong or weak civil cases will settle or reach a conclusion prior to reaching a conclusion at trial (Eisenberg 1989). Litigants who take cases to trial do so partly because they can afford to pursue trial litigation and, presumably, because they sense some reasonable level of uncertainty_factual or legal—as to a case's outcome (Priest and Klein 1984). This subpool of cases that withstands settlement or withdrawal, motions for directed verdicts and summary judgments, and other dispositions more likely comprises cases whose underlying merits reside somewhere in the gray middle area. A similar set of filters arise anew during the posttrial appeals process (Priest and Klein 1984; Revesz 2000). These various selection filters influence the case stream over time and in a manner that generates a skewed subset of appeals. The data allow us to account for one aspect of the selection processes at work: the decision to undertake an appeal after trial.

6. If one includes the nonadverse appeals, then the overall appeal rate is 14.4 percent. We do not compute reversal rates using nonadverse appeals because of the ambiguity of which party benefited. 


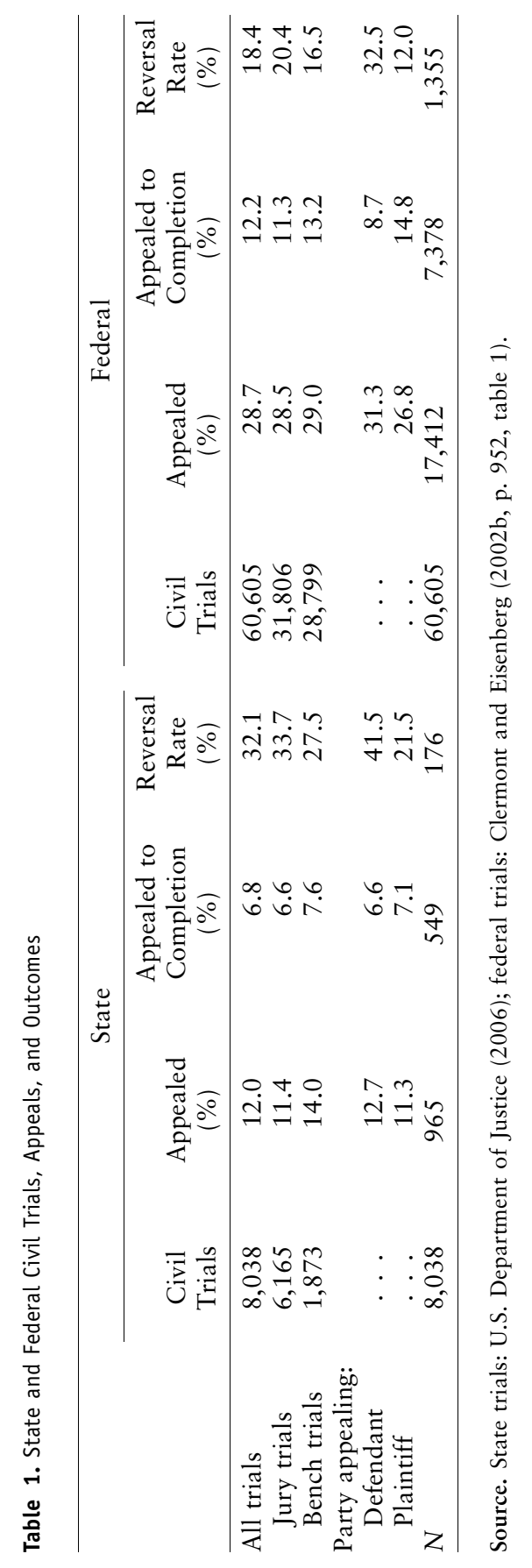




\section{INITIAL OBSERVATIONS}

We now turn to those cases that initiated the appeals process, explore appeal rates and appellate outcomes, and assess how they vary across trial, party, and case types. The left-hand columns of Table 1 report the basic pattern of state court appeals. For ease of comparison, the table's right-hand columns present the same information for appeals in federal court. The federal data cover the period 1988-97.

\subsection{The Vanishing Appeal?}

If state civil complaints that result in a trial on the merits are becoming increasingly rare over time (Galanter 2004), rarer still, as Table 1 illustrates, are the 12 percent of trial judgments that saw initiation of the appeals process. Fewer trials still ( 6.8 percent) resulted in an appellate court decision. Assessing whether the 12 percent appeal and the 6.8 percent appeal-to-completion rates are large or small, and how they might trend over time, requires context. Regrettably, detailed time series on state court appeals from trials data are not available. ${ }^{7}$ Our crosssectional data provide only a snapshot of the state civil appeals world rather than a longitudinal picture of trends over sustained periods of time. With directly relevant data lacking, we turn instead to other sources for context.

Data on federal civil appeals provide one reference point for state civil appeals data, albeit an imperfect one. Table 1 illustrates a discernable difference in federal and state appellate courts in terms of appeals rates. At first glance, Clermont and Eisenberg's (2002b) federal triedcase appeals rate (28.7 percent) suggests that our state appeals rate (12 percent) may be small both in comparative and absolute terms. Structural differences between the streams of federal and state appeals, however, help explain the difference in federal and state appeals rates. Important differences in the types of claims pursued in state and federal appellate courts might account for appeals rate differences. For example, to access the federal court system, litigants must either raise a federal question (28 U.S.C. sec. 1331) or plead for damages that now exceed $\$ 75,000$ and establish diversity between parties (28 U.S.C. sec. 1332[a]). Either

7. The best available data on trial court filings and appellate court dispositions are from the National Center for State Courts annual caseload statistics, available online for 1998-2005 (see National Center for State Courts, CSP: Court Statistics Project [http:// www.ncsconline.org/D_Research/csp/CSP_Main_Page.html]). But these data do not separately report on appeals of tried cases. 
jurisdictional requirement might route systematically higher stakes cases into federal courts and away from state courts. Just as higher stakes cases tended to be litigated to trial more than their lower stakes counterparts, higher stakes cases might similarly exert upward pressure on decisions to appeal (Gross and Syverud 1991; Posner 1998). Therefore, if federal trials typically involve higher stake claims than those pursued in state trials, we should expect the federal appeals rate to exceed the state appeals rate. ${ }^{8}$

A steady diminution of trial activity over time might also contribute to the differences in federal and state appeals rates presented in Table 1. Galanter's (2004) important study of trial activity and rates documents a profound and sustained reduction in civil trial activity in federal and state courts. In light of a decline in trial activity as a percentage of case filings, one might expect a similar decline in litigants' appetite for posttrial appeals. Insofar as the Clermont and Eisenberg (2001, 2002b) studies of federal appeals involve an earlier time period (1988-97) than our study of state appeals (2001-5 appeals of cases tried in 2001), our finding of a lower state appeals rate might be due to the different time periods of the two studies and capture a downturn in appeals activity. This alternative explanation, however, assumes that federal and state trial and appeals rates trend similarly in both magnitude and direction.

The influence of motor vehicle cases on state courts also contributes to the difference between state and federal appeals rates. Motor vehicle cases account for 35.1 percent of our pool of state trials and are by far the most common case type. Such cases account for a much smaller fraction of federal trials (Eisenberg et al. 1996). The appeal rate for motor vehicle cases ( 4.0 percent), however, is the lowest across all individual case types. Consequently, the sheer number of motor vehicle cases and their low appeal rate combine to depress the overall state appeals rate. The overall state appeals rate increases from about 12 to 16.3 percent, somewhat closer to the federal appeals rate ( 28.7 percent), if one disregards state motor vehicle cases. Even after such an adjustment, however, a sizable gap between the state and federal appeals rates persists.

Regardless of whether one regards the overall state civil appeals rate (12 percent) as large or small, the overall rate masks important variation

8. Although the intuition that structural differences between federal and state courts might route systematically higher stakes cases into federal courts strikes us as plausible, it bears noting that the intuition lacks empirical verification. Our data do not permit reliable assessments about the actual case in controversy. 
across party and trial types as well as case types. These observed variations largely track variations observed in the federal system. As Table 1 illustrates, defendants who lost at trial were more likely than plaintiffs to initiate an appeal (12.7 versus 11.3 percent). Our findings comport with party appeal rates in the federal context, although Clermont and Eisenberg (2002b) report a slightly larger gap between defendant- and plaintiff-initiated appeals (31.3 versus 26.8 percent). State litigants were more likely to appeal bench than jury trial decisions (14.0 versus 11.4 percent). Clermont and Eisenberg (2002b) found a numerically small gap in appeal rate between trial types (29.0 versus 28.5 percent); the appeal rate gap between trial types in our study achieved statistical significance $\left(\chi^{2}=9.088, p<.003\right)$. The highest appeals rate combination belonged to defendants who lost at a bench trial. The combination associated with the lowest appeals rate involved plaintiffs who lost in front of a jury.

In addition to party and trial type variation, as Table 2 shows, appeals rates also varied, sometimes substantially, across case types. Although 12 percent of all state-tried cases were appealed, professional (nonmedical) malpractice, employment contracts, and product liability cases were appealed at rates far above the mean $(30.9,29.5$, and 25.6 percent, respectively). As previously discussed, motor vehicle cases were the least likely case type to generate an appeal ( 4.0 percent). If differences in case stakes help explain differences in the federal and state appeals rates, similar differences might also explain variations in appeals rates across state case types. For example, the appeals rate for professional malpractice claims may exceed that of motor vehicle claims because of differences in the financial stakes contested in such cases.

\subsection{Appeal Dropouts}

If comparatively few litigants in state trials pursued an appeal, fewer still pursued an appeal to a decision on the merits. Table 1 shows that of the 965 cases that initiated the appeals process, 549 pursued an appeal to completion. ${ }^{9}$ Appeals that dropped out prior to decision were resolved through settlement, withdrawal, or other disposition. Federal litigants displayed a similar, if slightly more severe, pattern. While just over 43 percent of all state appeals were resolved prior to completion, more than one-half (57.6 percent) of the federal appeals settled prior to completion.

9. By "completion," we mean an appeals court decision was entered affirming or reversing or remanding to the trial court. 


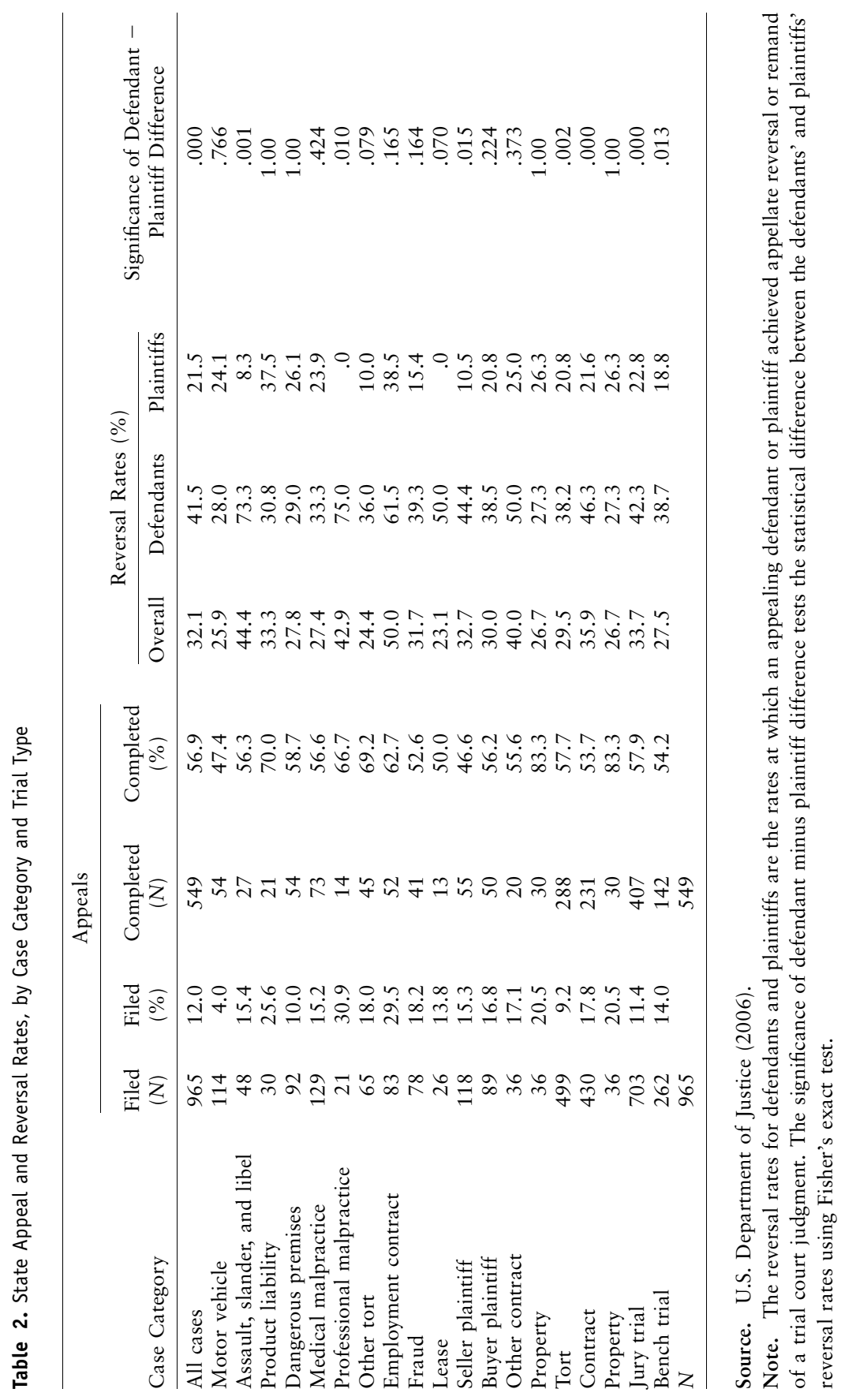


Thus, once a notice of an appeal was filed, state litigants were more likely than their federal counterparts to pursue an appeal to completion.

As Table 1 illustrates, although state appeals-to-completion rates varied across party and trial types as well as case categories, they varied less noticeably than appeals rates. Although defendants who lost at trial were more likely than plaintiffs to initiate an appeal, they were slightly less likely to pursue their appeals to a completion on the merits $(6.6$ versus 7.1 percent). Regarding trial types, bench trials were more likely to be appealed and to be appealed to completion ( 7.6 versus 6.6 percent) than jury trials. Both of these trends comport with Clermont and Eisenberg's (2002b) study of federal appeals.

Table 2 reveals how state appeals-to-completion rates varied across case types. With the overall 56.9 percent appeals-to-completion rate serving as a reference point, product liability, other tort, and property appeals were more likely pursued to completion by litigants. All had completion rates of at least 69 percent. In contrast, motor vehicle and seller plaintiff appeals were more likely to be resolved through settlement or otherwise; both case types had appeal completion rates of less than 50 percent.

Focusing on those appeals pursued to completion does not account for the sizable number of appeals initiated but resolved prior to appellate court decision through settlement, withdrawal, or other pretrial disposition. What might explain the overall 43.1 percent appeals dropout rate? Table 3 charts state civil appeals' attrition from trial court decision through a state's initial appeals court and to a state's highest appellate court. Interestingly, only 24 (or .3 percent) cases from our sample persisted through an accepted appeal by a state's highest court.

Clearly, legal strategy plays an important role in explaining why litigants initiate but do not complete appeals (LoPucki and Weyrauch 2000). By launching an appeal, a party can impose additional litigation costs on an opponent, establish a risk of loss of a trial court victory, delay final disposition of a case, and encumber a trial court award (Dalton 1985). While trial courts' decisions disposed of the overwhelming majority ( 88 percent) of tried state civil claims, for some percentage of litigants a trial court judgment is best understood as an opening bid to influence the settlement process that persists even after a notice of appeal has been filed.

Setting aside purely strategic appeals, some degree of settlement activity results from the normal forces at work in litigation at the posttrial stage (Hyman et al. 2007). Moreover, on some level, appeals settlement 


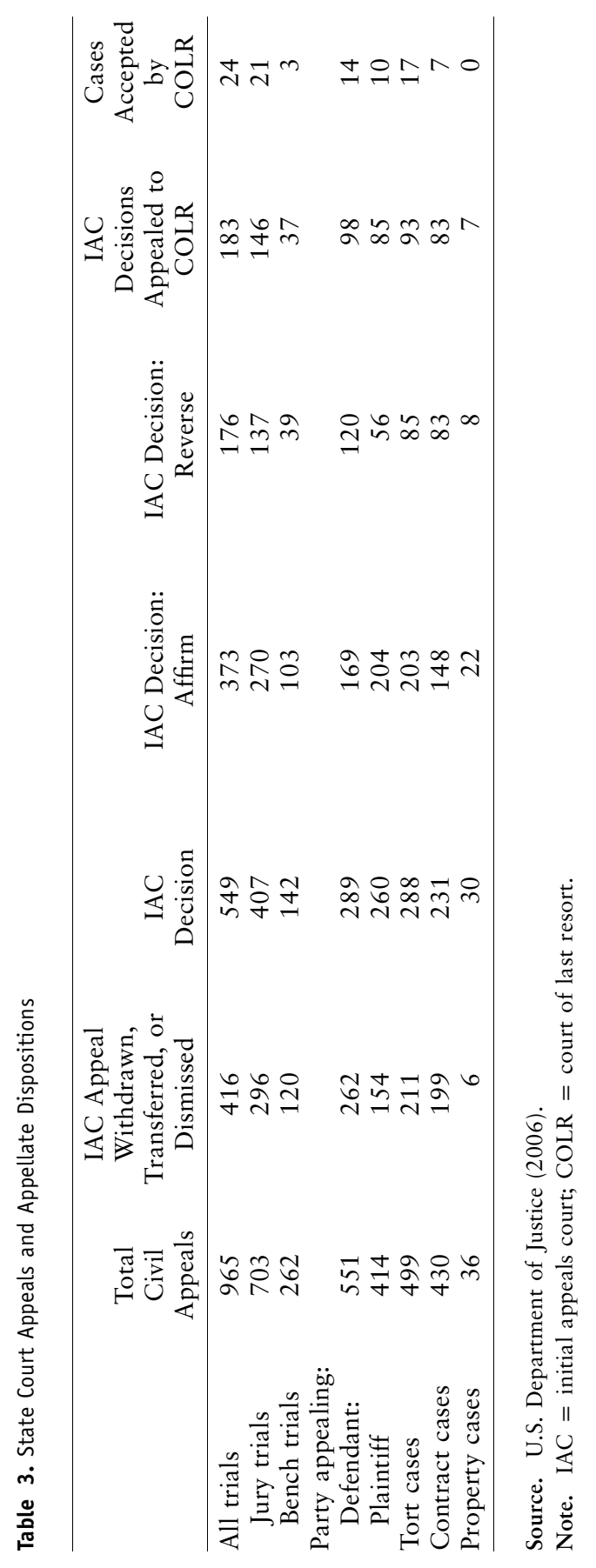


activity reflects an increase in formal institutional activity designed to promote settlements during the appeals process. For example, state appeals courts in Michigan operate a settlement program, which became fully operational in February 1998 (McNally 2000). Whether appeals settlement programs such as Michigan's stimulate cases to settle that otherwise would not is not clear. Nevertheless, such programs illustrate institutional commitments to appellate settlement.

\subsection{Appeal Outcomes}

Theory and folklore influence important perceptions about the outcome of appeals. Selection theory implies that, similar to trial outcomes, appeals outcomes (reverse or affirm) should be roughly similar and distributed equally between plaintiffs and defendants (Priest and Klein 1984). Attorney folklore also emphasizes the insulation of jury verdicts from reversal by appellate courts (see, for example, Somerville 1992). Neither theory nor folklore, however, satisfactorily explains our major findings. Appeals courts were far more likely to affirm than reverse a trial court decision (67.9 versus 32.1 percent). Moreover, appeals courts were more inclined to reverse jury than judge decisions. Finally, defendants were more successful than plaintiffs in reversing an adverse trial outcome.

As noted above, unrefined case-selection considerations suggest that state trials and appeals should approximate 50 percent success for plaintiffs and defendants. At the state trial court level, selection theory reasonably describes the outcome distribution-at least at the aggregate level-as outcomes do not dramatically favor plaintiffs or defendants (U.S. Department of Justice 2004). However, aggregate win rates in trial courts mask substantial variation across case types. In 2001, for example, plaintiffs' trial win rates ranged from a high of 72.7 percent (mortgage foreclosure cases) to a low of 26.8 percent (medical malpractice cases) (U.S. Department of Justice 2004).

Regardless of how well selection theory predicts state trial outcomes, state appellate outcomes are not close to 50 percent wins for plaintiffs and defendants. As Table 1 shows, we find an overall 32.1 percent reversal rate. This rate is closer to the 18.4 percent federal appeals reversal rate that Clermont and Eisenberg (2002b) found than to the (approximately) 50 percent rate that basic selection theory predicts. ${ }^{10}$ Thus, the

10. The approximately 70 percent higher rate of reversal of state trials than federal trials warrants future study. The higher state reversal rate is not a consequence of a different 
filtering mechanisms and case type mix that yielded an aggregate trial success rate not too far from 50 percent applied differently to filtering decisions to appeal. The predominance of affirmance over reversal is comforting since high reversal rates imply high trial court error rates or troublingly high rates of appellate court and trial court disagreement.

More dramatic is the starkly asymmetric distribution of appellate outcomes between plaintiffs and defendants and jury and bench trials. As Table 1 shows, defendants were far more likely than plaintiffs ( 41.5 versus 21.5 percent) to successfully reverse an adverse trial outcome. Indeed, from the perspective of a plaintiff victorious at trial, the appeals process offered a chance to retain victory not far from what a coin flip would predict. For defendants, by contrast, victories at trial were far more secure. Moreover, as Table 2 illustrates, the reversal rate difference substantially favored defendants in both bench and jury trials and in all but one case type. The exceptional case type, product liability, had only 21 completed appeals, and the difference in reversal rate did not approach statistical significance. As the final column in Table 2 illustrates, the overall difference in defendant and plaintiff reversal rates (41.5 versus 21.5 percent) achieved statistical significance, along with a few individual case types. ${ }^{11}$

Table 2 also conveys the level of variation across case types in terms of the defendant advantage at the appellate level. In five of the 14 case types considered, the defendants' reversal rate met or exceeded 50 percent. In none of the case types considered did the plaintiffs' reversal rate exceed 40 percent. Thus, defendants emerged from the state appellate process in a far better position than they left the trial court.

Finally, although bench trials were more likely than jury trials to involve an appeal (14 versus 11.4 percent), Table 1 shows that, contrary to conventional wisdom, appellate courts were kinder to judge than to jury decisions (27.5 versus 33.7 percent reversal rate). Moreover, the reversal rates favored defendants across trial types. As Table 2 illustrates, these asymmetrical differences achieved statistical significance.

On balance our findings so far are consistent with prior research on federal courts (Clermont and Eisenberg 2001, 2002b), and they suggest an appeals court tilt favoring defendants, especially defendants who lost

mix of case types because only one category of federal cases, fraud, achieves the overall state reversal rate of about 32 percent. No other federal case category has a reversal rate as high as 30 percent (see Clermont and Eisenberg 2002b, pp. 954-55, table 2).

11. The case types that achieved statistical significance include assault, slander and libel, professional (nonmedical) malpractice, and seller plaintiff cases. 
in a jury trial. Because the evidence is descriptive, however, it can easily mask confounding factors, including the trial court's behavior, the decision to appeal, and posttrial settlement conduct. To explore whether our results are an artifact of factors not considered, we proceed to more formally model both the decision to appeal and the appellate case outcome.

5. EVALUATING COMPETING EXPLANATIONS FOR A DEFENDANT ADVANTAGE BY MODELING APPEALS

As Section 2 suggests, theory supplies two plausible explanations for our asymmetrical appellate outcomes. More formal models-and empirical testing of those models-should inform assessments about each explanation's explanatory power. Given the observational nature of our data, we cannot conclusively establish causal inference relating to the asymmetric reversal rate. Nevertheless, the asymmetrical distribution of appeals outcomes warrants a more statistically sophisticated explanatory effort. The complete trial outcome data available allow us the unusual opportunity to account for the flow of cases to appellate courts as well as the appellate outcomes.

Efforts to model appellate outcomes must account, first, for the selection bias generated by the necessary decision to appeal a trial court verdict and, second, for the outcome of the appeal itself. If appellate courts see plaintiff and defendant posttrial appeals that differ in quality, the decision to appeal may be generating the unbalanced appellate outcomes. To account for a selection effect generated by the predicate decision to pursue (and complete) an appeal and, in turn, how it might influence the outcome of an appealed case, we used a Heckman probit selection model. This model did not suggest that the selection of cases to appeal was driving the appellate outcome pattern, so we also report simple models of appellate outcomes limited to cases that were appealed.

\subsection{Testing Hypotheses by Modeling the Decision to Appeal and the} Appeal Outcome

What variables should appellate models include? With respect to the decision to appeal, parties' perceptions (correct or not) about how appellate courts react to jury trials compared with bench trials, and to plaintiff trial court wins compared with defendant wins, likely inform litigants. To capture this possibility, we include dummy variables sig- 
naling whether a case was tried to a jury or judge and whether a plaintiff or defendant prevailed.

We also expect that a state and particular case type's reversal culture influences a decision to pursue an appeal. For each state ${ }^{12}$ and case category, we computed an overall reversal rate. For example, the reversal rates in Georgia and New Jersey were 12.5 and 56.3 percent, respectively. Similarly, reversal rates for various case types ranged from 50 percent (employment contract cases) to 23.1 percent (lease cases). Holding all else constant, we expect that parties seeking to reverse a trial court decision would be more reluctant to pursue an appeal in states with lower reversal rates or involving case types with lower reversal rates.

In addition to varied reversal rates, case types also exercise important influence over other factors. For example, case types influence the routing of cases to either judges or juries and display sometimes sharply different trial outcomes (Clermont and Eisenberg 1992). Case types also influence various trial facets, such as case disposition time (Heise 2000). Given case types' wide-ranging influences on the civil justice system, we also anticipate that case types influence the appeals process. We therefore include a dummy variable for each of our 14 case types other than a reference category.

Individuals, corporations, and governments vary in their appetite for and behavior in litigation (Eisenberg and Farber 2003), and it is reasonable to assume that such variation persists into the appeals process. To account for this variation, we use dummy variables to identify cases involving corporate plaintiffs, corporate defendants, and government plaintiffs. ${ }^{13}$ The litigant characteristics are salient regardless of the trial outcome. For example, to the extent that individual litigants believe that corporations behave differently in the litigation context, such differences would presumably present regardless of whether the corporation won or lost at trial. Moreover, because litigants' decisions about whether to appeal may vary over time, we include the year the lawsuit was initially filed to help control for any linear time trend in our data. Finally, to account for state-level effects, we include state dummy variables for those states with more than one sampled county.

Efforts to model the outcome of an appeal call for a similar, although

12. The "other states" dummy variable includes six states (Georgia, Hawaii, Massachusetts, North Carolina, Virginia, and Wisconsin) in which no more than one appeal was reversed during the time frame of our study.

13. We focus on these particular pairings in an effort to tether this study to prior studies. In any event, the inclusion of other pairings does not disturb our core findings. 
slightly different, set of independent variables. Analyzing the determinants of appellate court outcomes (reversals) is our principal interest, and, among the array of plausible independent variables, our primary focus involves trial type (bench versus jury) and trial outcome (defendant or plaintiff victory). Our descriptive results, presented in Tables 1 and 2 , suggest that appellate reversals were more likely for defendants who lost in jury trials. Other independent variables, such as case types, party types, and the year the appeal was filed, are obvious candidates for inclusion given the import of these variables for the decision to file an appeal as well as for the trial court outcome. To account for possible state-level effects on the appellate outcome, we include dummy variables for each state and a dummy variable signaling those states that have more than one sampled large county. Finally, because outcomes of individual appeals within a county might not be independent of one another, we treat appeals as clustered at the county level, resulting in adjusted standard errors.

\subsection{Results}

Table 4 reports results of the key variables in the appeals outcome portion of our selection model 1 . The selection model includes all tried cases. Our findings show that, similar to our descriptive findings, plaintiffs who won jury trials were more likely to be reversed on appeal (coefficient $=.532, p<.001$ ). Focusing only on jury trials, a test of the difference between the dummy variables "defendant won jury trial" and "plaintiff won jury trial" achieved statistical significance $\left(\chi^{2}=15.30\right.$, $p<.001)$, which further suggests important differences between how appeals courts treat defendant and plaintiff trial court victories. Since the selection parameter, $\rho$, did not achieve statistical significance, we also report a logit model limited to appellate outcomes in those cases appealed to conclusion. ${ }^{14}$ In the logit model, after accounting for case type and other variables, the average predicted probability of reversing a plaintiff trial win was .42 , and the average predicted probability of reversing a defendant trial win was .23.

For jury trials, the finding of higher reversal rates of plaintiff trial

14. The logit model yielded a slightly more accurate classification of appellate outcomes than did a similar probit model. We also explored a two-level multilevel model using a random intercept for county-level effects and a three-level multilevel model using random intercepts at the county and state levels. In both models the plaintiff-defendant reversal rate differences were highly statistically significant (see Gelman and Hill [2007] for a discussion). 
Table 4. Models of State Appellate Outcome and the Decision to Appeal

\begin{tabular}{|c|c|c|c|c|}
\hline \multirow{3}{*}{ Appeal outcome: } & \multicolumn{2}{|c|}{ Model 1} & \multicolumn{2}{|l|}{ Model 2} \\
\hline & & & & \\
\hline & & & & \\
\hline Defendant won bench trial & \multicolumn{2}{|c|}{ Reference } & \multicolumn{2}{|c|}{ Reference } \\
\hline Plaintiff won bench trial & .174 & $(.184)$ & $.914 *$ & $(.465)$ \\
\hline Defendant won jury trial & .099 & $(.164)$ & .123 & $(.328)$ \\
\hline Plaintiff won jury trial & $.532 * *$ & $(.164)$ & $1.189 * *$ & $(.358)$ \\
\hline \multicolumn{5}{|l|}{ States: } \\
\hline Arizona & \multicolumn{2}{|c|}{ Reference } & \multicolumn{2}{|c|}{ Reference } \\
\hline California & .065 & $(.472)$ & -1.807 & $(1.254)$ \\
\hline Connecticut & -.032 & $(.507)$ & -.929 & $(1.287)$ \\
\hline Florida & .237 & $(.476)$ & -1.058 & $(1.235)$ \\
\hline Illinois & .480 & $(.521)$ & -1.084 & $(1.327)$ \\
\hline Indiana & $.323^{*}$ & $(.149)$ & $.489 *$ & $(.233)$ \\
\hline Kentucky & .214 & $(.143)$ & $.832 * *$ & $(.230)$ \\
\hline Michigan & -.109 & $(.173)$ & .110 & $(.268)$ \\
\hline Minnesota & $.712 * *$ & $(.161)$ & $.662 * *$ & $(.223)$ \\
\hline Missouri & -.005 & $(.153)$ & -.328 & $(.238)$ \\
\hline New Jersey & .623 & $(.497)$ & -.473 & $(1.314)$ \\
\hline New York & .069 & $(.157)$ & $-.575 * *$ & $(.208)$ \\
\hline Ohio & -.053 & $(.503)$ & -2.071 & $(1.307)$ \\
\hline Pennsylvania & .370 & $(.464)$ & -1.284 & $(1.248)$ \\
\hline Texas & .251 & $(.493)$ & -1.083 & $(1.288)$ \\
\hline Washington & -.117 & $(.158)$ & -.283 & $(.226)$ \\
\hline Other states & $-.682 * *$ & $(.182)$ & $-1.270 * *$ & $(.435)$ \\
\hline Multicounty state & -.261 & $(.445)$ & 1.305 & $(1.224)$ \\
\hline \multicolumn{5}{|l|}{ Case types: } \\
\hline Motor vehicle & \multicolumn{2}{|c|}{ Reference } & \multicolumn{2}{|c|}{ Reference } \\
\hline Dangerous premises & .375 & $(.206)$ & .082 & $(.535)$ \\
\hline Product liability & $.790 *$ & $(.318)$ & .371 & $(.598)$ \\
\hline Assault, slander, and libel & $.829 * *$ & $(.250)$ & 1.066 & $(.587)$ \\
\hline Medical malpractice & .412 & $(.246)$ & .111 & $(.529)$ \\
\hline Professional malpractice & $1.052 *$ & $(.438)$ & .976 & $(.755)$ \\
\hline Other tort & .529 & $(.301)$ & -.170 & $(.570)$ \\
\hline Fraud & .536 & $(.373)$ & .200 & $(.750)$ \\
\hline Seller plaintiff & .414 & $(.303)$ & .161 & $(.575)$ \\
\hline Buyer plaintiff & .486 & $(.293)$ & .149 & $(.538)$ \\
\hline Employment contract & $1.180^{* *}$ & $(.282)$ & $1.281^{*}$ & $(.520)$ \\
\hline Lease & .344 & $(.433)$ & -.022 & $(.856)$ \\
\hline Other contract & $.712 *$ & $(.329)$ & .799 & $(.635)$ \\
\hline Property & $1.028 * *$ & $(.276)$ & .405 & $(.556)$ \\
\hline Year case filed & -.059 & $(.042)$ & -.045 & $(.070)$ \\
\hline \multicolumn{5}{|l|}{ Litigant characteristics: } \\
\hline Government plaintiff & .285 & $(.324)$ & .201 & $(.676)$ \\
\hline Corporate plaintiff & .150 & $(.092)$ & .302 & $(.188)$ \\
\hline Corporate defendant & -.009 & $(.113)$ & -.110 & $(.221)$ \\
\hline Constant & 115.537 & $(84.123)$ & \multicolumn{2}{|c|}{$88.233(140.531)$} \\
\hline$N$ & \multicolumn{2}{|c|}{$\ldots$} & \multicolumn{2}{|c|}{545} \\
\hline Log likelihood & \multicolumn{2}{|l|}{$\ldots$} & \multicolumn{2}{|l|}{-308.071} \\
\hline \multicolumn{5}{|l|}{$\begin{array}{l}\text { Hosmer-Lemeshow goodness of } \\
\text { fit }\end{array}$} \\
\hline Pseudo $R^{2}$ & $\cdots$ & & .100 & -.21 \\
\hline Appeals classified correctly (\%) & $\ldots$ & & 71.4 & \\
\hline Reduction in classification error & & & & \\
\hline from naive model & $\cdots$ & & 10.9 & \\
\hline & 142 & & & \\
\hline
\end{tabular}


Table 4. continued

\begin{tabular}{|c|c|c|c|c|}
\hline & \multicolumn{2}{|c|}{ Model 1} & \multicolumn{2}{|l|}{ Model 2} \\
\hline \multicolumn{5}{|l|}{ Decision to appeal $(N=7,998)$ : } \\
\hline \multicolumn{5}{|l|}{ Trial outcomes: } \\
\hline Defendant won bench trial & \multicolumn{2}{|c|}{ Reference } & \multicolumn{2}{|l|}{ Reference } \\
\hline Plaintiff won bench trial & $-.242 * *$ & $(.079)$ & $-.433 * *$ & $(.143)$ \\
\hline Defendant won jury trial & -.104 & $(.089)$ & -.219 & $(.159)$ \\
\hline Plaintiff won jury trial & .115 & $(.090)$ & .221 & $(.162)$ \\
\hline State reversal rate & $-.008^{*}$ & $(.003)$ & $-.017^{*}$ & $(.007)$ \\
\hline Case type reversal rate & $.048 * *$ & $(.006)$ & $.091 \% *$ & $(.010)$ \\
\hline Multicounty state & .075 & $(.095)$ & .160 & $(.182)$ \\
\hline \multicolumn{5}{|l|}{ Case types: } \\
\hline Motor vehicle & \multicolumn{2}{|c|}{ Reference } & \multicolumn{2}{|l|}{ Reference } \\
\hline Dangerous premises & $.322 * *$ & $(.085)$ & $.711 * *$ & $(.172)$ \\
\hline Product liability & $.579 * *$ & $(.149)$ & $1.145^{* *}$ & $(.254)$ \\
\hline Assault, slander, and libel & -.171 & $(.137)$ & -.250 & $(.240)$ \\
\hline Medical malpractice & $.667 * *$ & $(.077)$ & $1.350 * *$ & $(.153)$ \\
\hline Professional malpractice & $.369 *$ & $(.156)$ & $.686 * *$ & $(.262)$ \\
\hline Other tort & $.846 \% *$ & $(.080)$ & & \\
\hline Fraud & $.513 \% *$ & $(.083)$ & $1.037 * *$ & $(.151)$ \\
\hline Seller plaintiff & $.414 * *$ & $(.085)$ & $.849 * *$ & $(.158)$ \\
\hline Buyer plaintiff & $.512 * *$ & $(.093)$ & $1.053 * *$ & $(.178)$ \\
\hline \multicolumn{5}{|l|}{ Employment contract } \\
\hline Lease & $.834 \% *$ & $(.195)$ & $1.652 * *$ & $(.371)$ \\
\hline Other contract & .032 & $(.117)$ & .117 & $(.212)$ \\
\hline Property & $.891 * *$ & $(.187)$ & $1.735^{* *}$ & $(.338)$ \\
\hline Year case filed & $-.050 * *$ & $(.017)$ & $-.093 *$ & $(.031)$ \\
\hline \multicolumn{5}{|l|}{ Litigant characteristics: } \\
\hline Government plaintiff & .246 & $(.217)$ & .437 & $(.381)$ \\
\hline Corporate plaintiff & .126 & $(.085)$ & .236 & $(.154)$ \\
\hline Corporate defendant & $.136 * *$ & $(.050)$ & $.238^{*}$ & $(.094)$ \\
\hline Constant & \multicolumn{2}{|c|}{$97.161 *(33.599)$} & \multirow{2}{*}{\multicolumn{2}{|c|}{$\ldots$}} \\
\hline Rho & .429 & $(.283)$ & & \\
\hline$N$ (outcomes) & \multicolumn{2}{|l|}{961} & \multicolumn{2}{|l|}{$\ldots$} \\
\hline Log likelihood & \multicolumn{2}{|l|}{$-3,105.72$} & \multicolumn{2}{|l|}{$-2,683.04$} \\
\hline \multicolumn{3}{|l|}{$\begin{array}{l}\text { Hosmer-Lemeshow goodness of } \\
\text { fit }\end{array}$} & \multirow{2}{*}{\multicolumn{2}{|c|}{$\underset{.087}{10.78}(p>.21)$}} \\
\hline Pseudo $R^{2}$ & \multicolumn{2}{|l|}{$\cdots$} & & \\
\hline
\end{tabular}

Source. U.S. Department of Justice (2006).

Note. Model 1 includes Heckman appeal outcome and decision-to-appeal equations; the dependent variable is reversal of the trial court decision. Model 2 includes separate logit appeal outcome and decision-to-appeal models; the dependent variable in the appeal outcome model is reversal of the trial court decision, and the dependent variable in the decisionto-appeal model is whether an appeal was filed. "Other states" consists of the six states (Georgia, Hawaii, Massachusetts, North Carolina, Virginia, and Wisconsin) that had no more than one appeal reversal. Robust standard errors are in parentheses. We estimated the models using the "heckprob" and "logit" commands in Stata (v.9.2). The naive model predicts affirmance in $100 \%$ of appeals.

* Statistically significant at the $5 \%$ level.

$*$ Statistically significant at the $1 \%$ level. 
144 / THE JOURNAL OF LEGAL STUdies / VOLUME 38 (1) / JANUARY 2009

victories is highly statistically significant in both models. For bench trials, the positive coefficients for "plaintiff won bench trial" suggest a similar pro-defendant direction, but the significance of this result is sensitive to model specification. So the defendant advantage persists in the models, but most strongly in jury trials. The models confirm that jury trials are more prone to reversal than are bench trials. The "plaintiff won jury trial" coefficient is larger than the "plaintiff won bench trial" coefficient in both models. And the "defendant won jury trial" coefficient is consistently positive relative to the reference category of "defendant won bench trial." But these results are not statistically significant. Overall, the regression model results are consistent with the results of Table 1 showing a large difference between plaintiff and defendant reversal rates and a more modest difference between bench trial and jury trial reversal rates.

\subsection{Discussion}

With respect to the attitudinal explanation, results from the regression models support the earlier descriptive findings and are consistent with an appellate court tilt favoring defendants, especially defendants who lost a jury trial. With respect to selection effects, we do not doubt that they are at work. But the consistent pattern of our results across case categories suggests that selection effects are unlikely to completely explain the appellate outcome pattern. In addition, a slight negative inference emerges from the selection model, yielding results similar to the nonselection logit model. This weakens (albeit indirectly) the selection hypothesis's implications for the limits of modeling appellate outcomes based on the sample of appealed cases. Taken together, our findings provide more support for the attitudinal hypothesis than the selection effect hypothesis.

\subsection{Implications for the Attitudinal Hypothesis}

In both models, a plaintiff jury trial victory is associated with an appeals court reversal at a statistically significant level. This finding comports with what the descriptive analyses implied, as well as with prior research on federal appeals, although with less breadth. Clermont and Eisenberg (2001, 2002b) found a federal court appeals outcome tilt favoring defendants who lost either bench or jury trials. Our findings are consistent with the federal findings, although the state court bench trial effects are less significant than the federal.

Do these findings imply that juries exert a level of pro-plaintiff bias 
that accounts for the overall perceived pro-plaintiff bias at the trial court level? This scenario is unlikely, especially insofar as trial court judges retain the legal authority to override jury decisions in civil cases. As well, a considerable and growing empirical literature suggests that, in general, judges and juries act in comparable ways when confronted with comparable cases (Kalven and Zeisel 1966; Eisenberg et al. 2005, 2006). If they do, we are left to explain why the appellate process treats judge and jury decisions, in general, and plaintiff and defendant jury trial outcomes, in particular, differently.

Whether the observed higher plaintiff reversal rate flows from trial courts favoring plaintiffs, appeals courts favoring defendants, or some combination of both remains unclear. Findings from other research that focuses on just this question (whether the trial courts exhibit bias or whether appeals courts assume trial court bias), however, provide little support for the actual trial court bias explanation (Lempert 1998; Saks 1998; Vidmar 1998). Because appeals courts' systematic disagreement with trial courts is strongest for jury verdicts favoring plaintiffs combined with aggregate trial court decisions that have not been demonstrated to favor plaintiffs over defendants, the interpretation that appellate court misperceptions about jurors' bias toward plaintiffs—rather than outright jury bias at trial-is currently the more plausible explanation. To be clear, we do not propose a conspiracy theory of concerted action by appellate judges. Instead, we only invoke the notion that appellate judges entertain some of the same misperceptions about trial court outcomes as the general populace and that these misperceptions influence appellate outcomes.

\subsection{Implications for Selection Hypothesis}

The combination of our positive and negative findings points us away from the selection hypothesis as a complete explanation for appellate outcomes.

5.5.1. Little Evidence of a Selection Effect Explanation. If selection effects alone were driving the appellate outcome pattern, one might expect more heterogeneity in that pattern. Selection-based models, such as those explored by Kessler, Meites, and Miller (1996), employ case-category-level differences, such as varying stakes, to help account for selection effects.

But, as noted above, Table 2 shows a strikingly consistent antiplaintiff pattern across many case categories.

Selection theory also predicts that the side with comparatively more at 
stake should be willing to settle its weakest cases and, in so doing, increase its win rate for those cases fully adjudicated (Clermont and Eisenberg 2001). The plaintiff win rate at trial was approximately 55.4 percent (U.S. Department of Justice 2004), and it remains possible that the slightly higher plaintiff trial win rate might evidence plaintiffs' higher stakes (Clermont and Eisenberg 2001). Just as plaintiffs' higher stakes in cases should boost their trial win rates, the selection hypothesis also predicts that the side with lower stakes (defendants) would appeal more often. However, although defendants did, in fact, appeal slightly more often than plaintiffs ( 12.7 versus 11.3 percent), this difference achieved only marginal statistical significance $\left(\chi^{2}=3.718, p<.054\right)$. Moreover, although defendants appealed more often than plaintiffs, defendants appealed to conclusion slightly less often than did plaintiffs ( 6.6 versus 7.1 percent), which is again a difference that is not significant $\left(\chi^{2}=.575, p<.448\right)$.

More important, however, is that plaintiffs, whose hypothesized higher case stakes should make them more selective about what cases to push to trial, should be equally careful about pushing only strong cases on appeal. ${ }^{15}$ If so, appeal reversal rates for plaintiffs would approximate the defendants' reversal rate, if not exceed it. As Table 2 shows, however, this was not the case, as defendants enjoyed a far higher appeals reversal rate than plaintiffs (41.5 versus 21.5 percent), and the difference in defendants' and plaintiffs' reversal rates was highly significant $\left(\chi^{2}=25.095, p<\right.$ $.001)$.

In addition, results from our selection (Heckman) model 1 do not support a selection explanation. Rho, a measure of the correlation in the error term in the separate selection and outcome equations, is statistically insignificant. Consequently, one cannot reject the hypothesis that the error terms from the selection and outcome equations are uncorrelated. The model provides no evidence that asymmetric reversal rates were a consequence of the selection of cases for appeal. ${ }^{16}$ One should be careful not to overly rely on this negative finding for two reasons. First, multiequation selection models are highly sensitive to specification error. Small changes in the selection model can substantially change outcome estimates (Briggs 2004). Second, we likely do not have the optimal set of variables to control for both selection and the second-stage outcome.

15. Although the economics of appeals differ substantially from the economics of trials, appeals are not costless.

16. Although the $\rho$ test statistic in Heckman selection models is sensitive to model specifications, our finding is robust across various alternative specifications of our core Heckman selection model specification. 
Nevertheless, because $\rho$ is not statistically significant and the sample size is reasonably large, the logit model may suffice. The HosmerLemeshow test of that model's fit, reported in Table 4, suggests that one cannot reject the hypothesis that the model fits the data well. That model's statistically significant influence of plaintiff wins in jury trials on the outcome of appeals provides additional evidence of the robustness of this central finding.

We also are mindful that our findings only indirectly challenge the selection effect hypothesis. Indeed, plausible counterarguments-especially those that our data and research design do not squarely addresswarrant careful consideration. For example, selection theory proponents may suggest that plaintiffs start with systematically weaker cases and then litigate them less effectively than do defendants. ${ }^{17}$ We are unaware of empirical support for such claims, however. Moreover, such claims are not theoretically persuasive. After all, at a general level, plaintiffs and defendants face similar (albeit not identical) economic incentives. These incentives should discipline plaintiffs and their attorneys and discourage weak cases. To the extent that the litigation process itself discourages case filings (Trubek et al. 1983), the pool of claims that begins the litigation process might be systematically stronger than the universe of potential legal claims. As well, our study involves appealed cases. By definition these cases have persisted through the entire trial process, including the pretrial motion stage, which, by design, also helps screen out extreme cases favoring either party. Despite our pool of appealed cases having survived multiple layers of filtering, we still found evidence of a pro-defendant appellate court tilt. This finding conflicts with the "plaintiff weak case" counterargument (Clermont and Schwab 2002).

5.5.2. Evidence of an Unexpected Selection Effect. Although we interpret our findings to more strongly support an attitudinal rather than a selection explanation for the asymmetrical distribution of state appellate court reversals, one should not disregard the selection theory altogether. In general, a more complete model of the litigation process would be desirable. The decision to file a lawsuit and the decision to pursue a case

17. One limitation on interpreting both federal and state court plaintiff-defendant asymmetric success on appeal is that the reversal rate is in part a function of what one believes the objectively correct trial win rate should be. If the objectively correct trial win rate in a case category differs from 50 percent, then one expects asymmetric plaintiff and defendant reversal rates on appeal (see Eisenberg [2004] and Spencer [2007] for a discussion). 
to trial likely influence the reversal pattern ultimately observed on appeal. Since our data begin with tried cases, such a study is beyond the scope of this paper.

And while selection theory may not explain asymmetric appellate outcomes within the state context or, according to Clermont and Eisenberg (2001), within the federal context, selection theory may help explain differences between the state and federal appellate settings.

At least two federal-state differences warrant note as they implicate selection theory. ${ }^{18}$ First, the federal and state appeals settings generated different appeal and reversal rates. Second, results from our more formal models were slightly narrower than the corresponding results from a federal appeals study. Specifically, where Clermont and Eisenberg (2001) find that appellate reversals are significantly associated with plaintiff bench and jury trial victories, we find a consistently significant association only with plaintiff jury trial victories.

As noted above, structural differences between federal and state cases likely contribute to the slightly different findings. We believe that selection effects generate distinctive streams of federal and state cases and that these distinctive streams of cases react differently in the appeals context. Within the federal and state appeals settings, strong evidence of a selection effect does not emerge. Slight differences between the federal and state appeals studies, however, hint at a possible selection effect. Thus, it is not the case that selection considerations find no support in our study. Rather, we believe selection effects might present in unexpected ways. ${ }^{19}$ With the benefit of empirical studies of the federal and state appeals settings, we are now in a better position to speculate whether and, if so, why this might be so. At this point, however, further empirical work is necessary to rigorously explore this possibility.

\subsection{Other Results}

Although our discussion emphasizes our independent variables of interest-trial outcomes-and their implications for the two hypotheses for the asymmetric appellate outcomes, a few other results warrant brief discussion. Among the litigant characteristics tested, although none achieved statistical significance, as it relates to the appeal outcome, the presence of a corporate defendant increased the probability that an ap-

18. Despite small differences in findings from the two studies, however, it remains important to keep in mind that any differences are overwhelmed by the similarities.

19. Indeed, Clermont and Eisenberg (2001, p. 153) found evidence in their study of federal appeals consistent with the selection theory. 
peal would be filed. This finding could suggest that corporate defendants with deep pockets were more able to participate in the appeals process or, in the alternative, to better manage the appeals process by virtue of their greater litigation experience. Any such suggestions, however plausible, extend beyond our data, as they relate to access to wealth and to litigation experience. Moreover, the absence of a statistically significant finding for the presence of a corporate plaintiff generates something of a dilemma, unless one is prepared to argue that corporate plaintiffs and defendants systematically differ in manners that implicate access to wealth and litigation experience.

Our decision-to-appeal model also includes variables designed to account for reversal culture for individual case types and states on the theory that a more favorable (higher) reversal rate should attract greater appellate activity. Although the sign and magnitude of the case type reversal rate control variable behaved as expected, the state reversal rate control variable behaved unexpectedly. ${ }^{20}$ Two factors might contribute to the state reversal rate's negative coefficient. First, some amount of measurement error owing to time lags may contribute to imprecision with our reversal rate variables. The critical moment in time for purposes of the hypothesized influence of reversal rates was when a litigant filed a motion for appeal. The reversal rate variables used in our model derive from actual appellate reversal counts from trials concluded in 2001. The average disposition for an appeal that persisted to an appellate court decision exceeded 463 days. Not only is it possible that state reversal rates may have varied over time in this study (2001-5), but they may also have varied between an appeal's filing and an appellate court ruling. Either possibility, if realized, would increase measurement error. Second, we also note that Table A1 illustrates that the case type reversal rate control variable is more uniformly distributed than the state counterpart. The unexpected direction of the state reversal culture might be partly due to its comparative greater variation.

\section{CONCLUSION}

This study provides the first systematic analysis of appeals from state court trials and the degree to which state appellate court decisions and opinions reflect trial-level activity. Less than 7 percent of tried cases are

20. Despite the unexpected sign for the state reversal rate variable, excluding it in alternative model specifications did not disrupt our core findings. 
appealed to conclusion at any appellate level. This is lower than the approximately 12 percent rate for federal litigation found in prior studies covering a different time period. Appeal and reversal rates differ substantially across case types and reach or exceed 50 percent of defendant appeals in five case categories, including employment litigation. Only .3 percent of tried cases are accepted for review by states' highest courts.

While state court reversal rates are noticeably higher than federal court reversal rates, state appellate courts, like federal courts, have a greater propensity to overturn jury rather than bench trial verdicts and plaintiff trial victories more than defendant trial victories. With respect to these asymmetric reversal rates, our findings favor an attitudinal rather than a pure selection explanation. That is, similar to the federal setting, state appellate reversals that tilt favorably to defendants who lost in a jury trial likely evidence appellate and trial courts' differing perceptions regarding the accuracy of jury trial outcomes.

Although our empirical findings suggest an asymmetric distribution of appellate outcomes, we remain mindful that plausible alternative interpretations exist, partly owing to incomplete data. Indeed, selection effects likely influence the appellate setting but in unanticipated ways that can be detected in part by comparing appellate outcomes between state and federal systems. For example, although the attitudinal hypothesis strikes us as more persuasive in explaining the distribution of reversals within the state and federal systems, selection effects provide a plausible possible explanation for differences in results between the state and federal systems. In addition, it is logically possible that our asymmetrical findings result from a trial court tilt favoring plaintiffs rather than misperceptions at the appeals court level. Moreover, it might be that jury trials are simply more prone to reversible error than bench trials. If so, however, we are left with having to explain why plaintiff jury trial victories (rather than plaintiff and defendant jury trial victories) are significantly more prone to reversal. Finally, our data do not permit reliable testing of the possible lure of precedent setting (Priest and Klein 1984, p. 52) and Galanter's (1974) repeat-player theory, both of which raise the specter of selection effects. Further empirical work, however, is necessary to rigorously test these explanations.

The existence of plausible (although, as of yet, empirically untested) alternative interpretations of our findings, however, does not detract from the practical implications that flow from our findings, not least of which is that the common wisdom regarding the sacrosanctity of trial jury verdicts, especially those favoring plaintiffs, may be misplaced. Find- 
ings from our study of state civil appeals should inform scholars as well as litigants and appellate judges.

\section{APPENDIX A}

Table A1. Descriptive Statistics of Variables

\begin{tabular}{|c|c|c|c|c|}
\hline Variable & Mean & SD & Min & Max \\
\hline Reversed trial court & .182 & .386 & 0 & 1 \\
\hline $\begin{array}{l}\text { Defendant won bench } \\
\text { trial }\end{array}$ & .083 & .275 & 0 & 1 \\
\hline Plaintiff won bench trial & .150 & .357 & 0 & 1 \\
\hline Defendant won jury trial & .375 & .484 & 0 & 1 \\
\hline Plaintiff won jury trial & .392 & .488 & 0 & 1 \\
\hline Arizona & .050 & .218 & 0 & 1 \\
\hline California & .157 & .364 & 0 & 1 \\
\hline Connecticut & .020 & .141 & 0 & 1 \\
\hline Florida & .072 & .258 & 0 & 1 \\
\hline Georgia & .016 & .124 & 0 & 1 \\
\hline Hawaii & .003 & .055 & 0 & 1 \\
\hline Illinois & .053 & .225 & 0 & 1 \\
\hline Indiana & .015 & .123 & 0 & 1 \\
\hline Kentucky & .019 & .137 & 0 & 1 \\
\hline Massachusetts & .030 & .170 & 0 & 1 \\
\hline Michigan & .048 & .214 & 0 & 1 \\
\hline Minnesota & .025 & .156 & 0 & 1 \\
\hline Missouri & .018 & .134 & 0 & 1 \\
\hline North Carolina & .013 & .113 & 0 & 1 \\
\hline New Jersey & .077 & .266 & 0 & 1 \\
\hline New York & .038 & .192 & 0 & 1 \\
\hline Ohio & .050 & .219 & 0 & 1 \\
\hline Pennsylvania & .097 & .295 & 0 & 1 \\
\hline Texas & .126 & .332 & 0 & 1 \\
\hline Virginia & .031 & .172 & 0 & 1 \\
\hline Washington & .026 & .159 & 0 & 1 \\
\hline Wisconsin & .016 & .124 & 0 & 1 \\
\hline Motor vehicle & .351 & .477 & 0 & 1 \\
\hline Assault, slander, and libel & .039 & .193 & 0 & 1 \\
\hline Product liability & .015 & .120 & 0 & 1 \\
\hline Dangerous premises & .115 & .319 & 0 & 1 \\
\hline Medical malpractice & .106 & .308 & 0 & 1 \\
\hline Professional malpractice & .008 & .092 & 0 & 1 \\
\hline Other tort & .045 & .207 & 0 & 1 \\
\hline Employment contract & .035 & .184 & 0 & 1 \\
\hline Fraud & .053 & .225 & 0 & 1 \\
\hline Lease & .023 & .151 & 0 & 1 \\
\hline Seller plaintiff & .096 & .295 & 0 & 1 \\
\hline Buyer plaintiff & .066 & .248 & 0 & 1 \\
\hline Other contract & .026 & .160 & 0 & 1 \\
\hline Property & .022 & .146 & 0 & 1 \\
\hline Year case filed & 1998.91 & 1.341 & 1985 & 2001 \\
\hline Government plaintiff & .008 & .091 & 0 & 1 \\
\hline Corporate plaintiff & .156 & .363 & 0 & 1 \\
\hline
\end{tabular}


152 / THE JOURNaL OF LEGAL STUdies / VOLUME 38 (1) / JANUARY 2009

Table A1. continued

\begin{tabular}{lrccr}
\hline Variable & Mean & SD & Min & Max \\
\hline Corporate defendant & .425 & .494 & 0 & 1 \\
State appeals review rate & 37.084 & 15.248 & 0 & 100 \\
Case type appeals review & & & & \\
$\quad$ rate & 29.589 & 6.069 & 23.077 & 50 \\
Multicounty state & .682 & .466 & 0 & 1 \\
\hline
\end{tabular}

Source. U.S. Department of Justice (2006).

Note. $N=8,038$ for all variables, except for reversed trial court, for which $N=965$.

\section{REFERENCES}

Barclay, Scott. 1999. An Appealing Act: Why Parties Appeal in Civil Cases. Evanston, Ill.: Northwestern University Press.

Briggs, Derek C. 2004. Causal Inference and the Heckman Model. Journal of Educational and Behavioral Statistics 29:397-420.

Clermont, Kevin M., and Theodore Eisenberg. 1992. Trial by Jury or Judge: Transcending Empiricism. Cornell Law Review 77:1124-74.

- 2001. Appeal from Jury or Judge Trial: Defendants' Advantage. American Law and Economic Review 3:125-64.

. 2002a. Litigation Realities. Cornell Law Review 88:119-53.

. 2002b. Plaintiphobia in the Appellate Courts: Civil Rights Really Do Differ from Negotiable Instruments. University of Illinois Law Review 2002: 947-77.

Clermont, Kevin M., Theodore Eisenberg, and Stewart J. Schwab. 2003. How Employment-Discrimination Plaintiffs Fare in Federal Courts of Appeals. Employee Rights and Employment Policy Journal 7:547-67.

Clermont, Kevin M., and Stewart J. Schwab. 2002. How Employment Discrimination Plaintiffs Fare in Federal Court. Journal of Empirical Legal Studies 1:429-58.

Dalton, Harlon L. 1985. Taking the Right to Appeal (More or Less) Seriously. Yale Law Journal 95:62-107.

Eisenberg, Theodore. 1989. Litigation Models and Trial Outcomes in Civil Rights and Prisoner Cases. Georgetown Law Journal 77:1567-1602.

- 2004. Appeal Rates and Outcomes in Tried and Nontried Cases: Further Exploration of Anti-plaintiff Appellate Outcomes. Journal of Empirical Legal Studies 1:659-88.

Eisenberg, Theodore, and Henry Farber. 2003. The Government as Litigant: Further Tests of the Case Selection Model. American Law and Economic Review 5:94-133.

Eisenberg, Theodore, John Goerdt, Brian Ostrom, and David Rottman. 1996. 
Litigation Outcomes in State and Federal Courts: A Statistical Portrait. Seattle Law Review 19:433-53.

Eisenberg, Theodore, John Goerdt, Brian Ostrom, David Rottman, and Martin T. Wells. 1997. The Predictability of Punitive Damages. Journal of Legal Studies 26:623-60.

Eisenberg, Theodore, Paula L. Hannaford-Agor, Valerie P. Hans, Nicole L. Waters, G. Thomas Munsterman, Stewart J. Schwab, and Martin T. Wells. 2005. Judge-Jury Agreement in Criminal Cases: A Partial Replication of Kalven and Zeisel's American Jury. Journal of Empirical Legal Studies 2: $171-206$.

Eisenberg, Theodore, Paula L. Hannaford-Agor, Michael Heise, Neil LaFountain, G. Thomas Munsterman, Brian Ostrom, and Martin T. Wells. 2006. Juries, Judges, and Punitive Damages: Empirical Analyses Using the Civil Justice Survey of State Courts 1992, 1996, and 2001 Data. Journal of Empirical Legal Studies 3:263-95.

Galanter, Marc. 1974. Why the "Haves" Come out Ahead: Speculations on the Limits of Legal Change. Law and Society Review 9:95-160.

- 2004. The Vanishing Trial: An Examination of Trials and Related Matters in Federal and State Courts. Journal of Empirical Legal Studies 1: 459-570.

- 2006. A World without Trials? Journal of Dispute Resolution 2006: 7-34.

Gelman, Andrew, and Jennifer Hill. 2007. Data Analysis Using Regression and Multilevel/Hierarchical Models. New York: Cambridge University Press.

Gross, Samuel R., and Kent D. Syverud. 1991. Getting to No: A Study of Settlement Negotiations and the Selection of Cases for Trial. Michigan Law Review 90:319-93.

Haydock, Roger, and John Sonsteng. 1990. Trial: Theories, Tactics, Techniques. St. Paul, Minn.: West Publishing.

Heise, Michael. 2000. Justice Delayed?: An Empirical Analysis of Civil Case Disposition Time. Case Western Reserve Law Review 50:813-49.

Hyman, David A., Bernard S. Black, Kathryn Zeiler, Charles Silver, and William M. Sage. 2007. Do Defendants Pay What Juries Award? Post-verdict Haircuts in Texas Medical Malpractice Cases, 1988-2003. Journal of Empirical Legal Studies 4:3-68.

Kalven, Harry, and Hans Zeisel. 1966. The American Jury. Boston: Little, Brown.

Kessler, Daniel, Thomas Meites, and Geoffrey Miller. 1996. Explaining Deviations from the Fifty-Percent Rule: A Multimodal Approach to the Selection of Cases for Litigation. Journal of Legal Studies 25:233-59.

Lempert, Richard. 1998. Why Do Juries Get a Bum Rap? Reflections on the Work of Valerie Hans. DePaul Law Review 48:453-62.

LoPucki, Lynn M., and Walter O. Weyrauch. 2000. A Theory of Legal Strategy. Duke Law Journal 49:1405-86. 
154 / THE JOURNAL OF LEGAL STUdies / VOLUME 38 (1) / JANUARY 2009

McNally, James N. 2000. Lessons Learned in the Court of Appeals Settlement Program. Michigan Bar Journal 79:488-93.

Merritt, Deborah J., and Kathryn A. Barry. 1999. Is the Tort System in Crisis? New Empirical Evidence. Obio State Law Journal 60:315-98.

Moller, Erik K., Nicholas M. Pace, and Stephen J. Carroll. 1999. Punitive Damages in Financial Injury Jury Verdicts. Journal of Legal Studies 28:283-339.

Posner, Richard A. 1985. The Federal Courts: Crisis and Reform. Cambridge, Mass.: Harvard University Press.

. 1998. Economic Analysis of Law. 5th ed. New York: Aspen.

Priest, George L., and Benjamin Klein. 1984. The Selection of Disputes for Litigation. Journal of Legal Studies 13:1-55.

Revesz, Richard L. 2000. Litigation and Settlement in the Federal Appellate Courts: Impact of Panel Selection Procedures on Ideologically Divided Courts. Journal of Legal Studies 29:685-710.

Robertson, James L. 1999. Reality on Appeal. Pp. 142-49 in The Litigation Manual: Special Problems and Appeals, edited by John G. Koeltl and John Kiernan. 3d ed. Chicago: American Bar Association.

Saks, Michael J. 1998. Public Opinion about the Civil Jury: Can Reality Be Found in Illusions? DePaul Law Review 48:221-43.

Segal, Jeffrey A., and Harold J. Spaeth. 2002. The Supreme Court and the Attitudinal Model Revisited. New York: Cambridge University Press.

Shavell, Steven. 1996. Any Frequency of Plaintiff Victory at Trial Is Possible. Journal of Legal Studies 25:493-501.

Siegelman, Peter, and John J. Donohue III. 1990. Studying the Iceberg from Its Tip: A Comparison of Published and Unpublished Employment Discrimination Cases. Law and Society Review 24:1133-66.

Somerville, George A. 1992. Standards of Appellate Review. Pp. 16-25 in Appellate Practice Manual, edited by Pricilla A. Schwab. Chicago: American Bar Association.

Spencer, Bruce D. 2007. Estimating the Accuracy of Jury Verdicts. Journal of Empirical Legal Studies 4:305-29.

Sullivan, Teresa A., Elizabeth Warren, and Jay Lawrence Westbrook. 1989. As We Forgive Our Debtors: Bankruptcy and Consumer Credit in America. New York: Oxford University Press.

Tigar, Michael. 1993. Federal Appeals: Jurisdiction and Practice. 2 d ed. Colorado Springs, Colo.: Shepard's/McGraw-Hill.

Trubek, David M., Austin Sarat, William L. F. Felstiner, Herbert M. Kritzer, and Joel B. Grossman. 1983. The Costs of Ordinary Litigation. UCLA Law Review 31:72-123.

U.S. Department of Justice. 2004. Office of Justice Programs. Bureau of Justice Statistics. Civil Justice Survey of State Courts, 2001: Civil Trial Cases and Verdicts in Large Counties, 2001. Washington, D.C.: U.S. Government Printing Office. 
2005. Appeals from General Civil Trials in 46 Large Counties, 2001-2005. Washington, D.C.: U.S. Government Printing Office.

- 2006. Supplemental Survey of Civil Appeals, 2001 (computer file). Conducted by National Center for State Courts. ICPSR No. 4539. Ann Arbor, Mich.: Inter-university Consortium for Political and Social Research.

Vidmar, Neil. 1998. The Performance of the American Civil Jury: An Empirical Perspective. Arizona Law Review 40:849-99. 